\title{
Effect of Blast Furnace Sludge (BFS) Characteristics on Suitable Recycling Process Determining
}

\author{
Mamdouh Omran ${ }^{1,2}{ }^{*}$, Timo Fabritius ${ }^{1}$, Timo Paananen ${ }^{3}$ \\ ${ }^{1}$ Process Metallurgy Research Group, Faculty of Technology, University of Oulu, Oulu, Finland \\ ${ }^{2}$ Mineral Processing and Agglomeration Lab, Central Metallurgical Research and Development Institute, Cairo, Egypt \\ ${ }^{3} \mathrm{SSAB}$ Europe, Raahe, Finland \\ Email: ${ }^{\star M a m d o u h . o m r a n @ o u l u . f i ~}$
}

How to cite this paper: Omran, M., Fabritius, T. and Paananen, T. (2017) Effect of Blast Furnace Sludge (BFS) Characteristics on Suitable Recycling Process Determining. Journal of Minerals and Materials Characterization and Engineering, 5, 185-197. https://doi.org/10.4236/jmmce.2017.54016

Received: May 18, 2017

Accepted: July 2, 2017

Published: July 5, 2017

Copyright (C) 2017 by authors and Scientific Research Publishing Inc. This work is licensed under the Creative Commons Attribution International License (CC BY 4.0). http://creativecommons.org/licenses/by/4.0/

\section{Open Access}

\begin{abstract}
The present study aims to give a detailed characterization of blast furnace sludge (BFS) by using different techniques, in order to determine the most effective recycling method to recover valuable metals from this waste. BFS is composed mainly of hematite, as its iron-bearing phase, and carbon, in addition to fractions of silicate and carbonate materials. The studied BFS shows relatively high contents of iron (Fe) (390 g. $\left.\mathrm{kg}^{-1}\right)$, and carbon (C) $\left(290 \mathrm{~g} \cdot \mathrm{kg}^{-1}\right)$, due to abundance of hematite and coke, while the concentration of zinc $(\mathrm{Zn})$ $\left(2.5 \mathrm{~g} \cdot \mathrm{kg}^{-1}\right)$ is low. The XRD analyses indicated that, hematite is more concentrated in the fine fraction $(<20 \mu \mathrm{m})$, while the coarser fraction $(90-250 \mu \mathrm{m})$ is dominated by calcite, quartz and X-ray amorphous coke. SEM-EDX analyses confirmed that particles rich in iron and zinc were detected in the fine fraction $(<20 \mu \mathrm{m})$ of the sludge. Due to high Fe and C content in BFS, it can be utilized as self-reducing material and briquetting represent a potential method for recycling of blast furnace sludge.
\end{abstract}

\section{Keywords}

Blast Furnace Sludge (BFS), Characterization, Recycling

\section{Introduction}

Blast furnace sludge (BFS) is a metallurgical waste generated by the iron-making process [1] [2]. This sludge is a mixture of oxides whose major components are iron oxides and coke fines, in addition to silicon, calcium, magnesium and minor heavy metals such as zinc, lead, and cadmium [3] [4]. Due to the sludge's high carbon and iron contents, it can be recycled in the furnace [5]. The presence 
of heavy metals as well as alkaline elements limits the utilization and direct recycling of blast furnace sludge [6]. The BFS is classified as harmful waste according to European Waste Catalogue [7], because BFS may contain toxic compounds like, cyanide (CN) [8] and mercury (Hg) [9]. The mineralogical composition of BFS has been studied by several researchers [2] [10], which has shown that BFS is composed mainly of hematite $\left(\alpha-\mathrm{Fe}_{2} \mathrm{O}_{3}\right)$, and coke (C), in addition to fractions of magnetite $\left(\mathrm{Fe}_{3} \mathrm{O}_{4}\right)$, calcite $\left(\mathrm{CaCO}_{3}\right)$, quartz $\left(\mathrm{SiO}_{2}\right)$, dolomite $\left(\mathrm{CaMgCO}_{3}\right)$, siderite $\left(\mathrm{FeCO}_{3}\right)$ and clay minerals. Most coke is usually found as $\mathrm{X}$-ray amorphous material [10].

Landfill is the conventional method of blast furnace sludge disposing. Landfills are closed areas which prevent the flow of water to surrounded areas. The flow of water from land filled with the waste materials has become a significant source of pollution of air, water and soil [2] [11]. For utilization of blast furnace sludge, several pyrometallurgical and hydrometallurgy processes have been proposed. However, most of these attempts still have some technical difficulties due to the insufficient knowledge about the characteristics and mode of occurrence of zinc and other harmful elements in these wastes. In order to choose a suitable process for recycling and recovery of BFS, the accurate knowledge of their characteristics is necessary.

The present work is a part of the work dealing with the characterization and utilization of blast furnace sludge generated from SSAB Europe Oy, Raahe, Finland. The objective of this study was to perform a detailed investigation of the mineralogical, chemical, physical and morphological characteristics of BFS. The study also provides an opportunity to examine the distribution, concentration and mode of occurrence of iron, carbon, zinc and other elements in the BFS, which can help to choose the suitable process for utilization of these wastes. The characterization of BFS was carried out by using X-ray diffraction (XRD), X-ray fluorescence (XRF), Granulometric analysis, and Scanning electron microscopy (SEM) coupled with Energy-dispersive X-ray spectroscopy (EDS).

\section{Generation of Blast Furnace Sludge at SSAB-Raahe-Finland}

SSAB is producing liquid steel via the blast furnace $(\mathrm{BF})$ - basic oxygen furnace (BOF) production route, and there are two sludges at the site. The amount of BF sludge and BOF sludge generated at the site are about 35,000 ton and 40,000 ton per year respectively [12]. The amount of BFS generated from the steel industry in Europe alone in the past decades is up to 500,000 ton of BFS each year [4] [10]. Blast furnace sludge (BFS) is generated in large quantities during the purification of flue gas leaving blast furnaces used in pig iron production [2]. A simplified flow sheet for flue gas purification and BFS generation process at SSAB (Raahe, Finland) is shown in Figure 1. Hot blast is blown into the lower part of the blast furnace and the dusty gas leaves the blast furnace at the top during the operation. The dust content of raw BF gas is very different from one plant to another and is also highly dependent on process conditions, varying from 5.5 - 


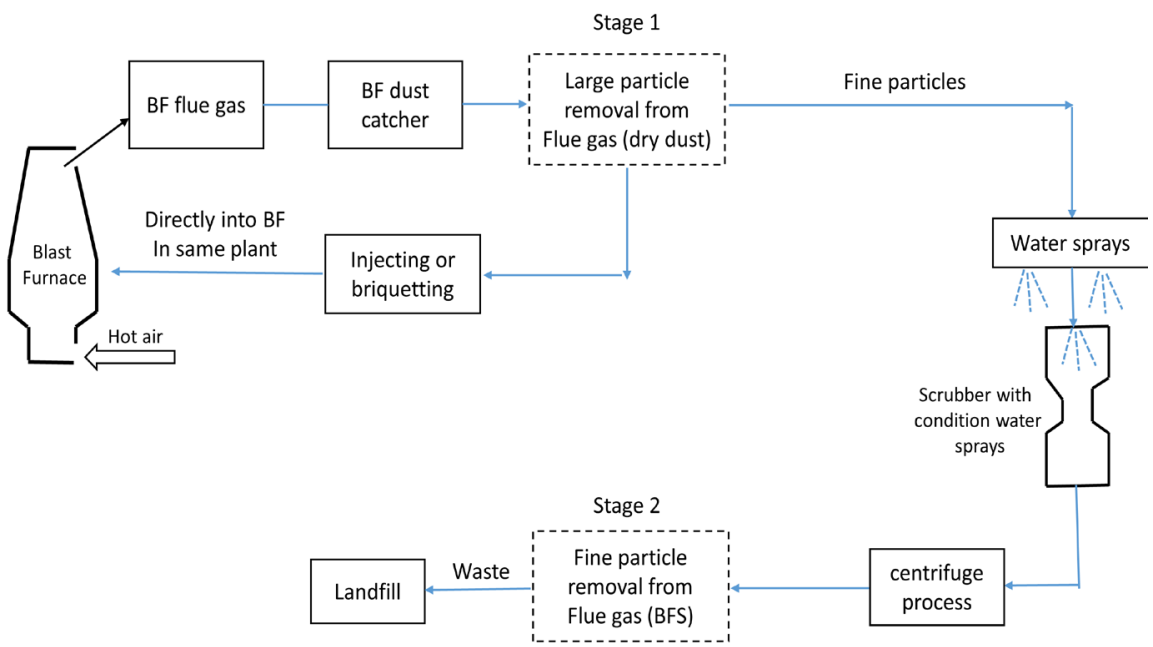

Figure 1. Flow sheet for flue gas purification process and BFS generation at SSAB (Raahe, Finland).

$40 \mathrm{~kg} / \mathrm{t}$ hot metal produced [13]. BF gas is usually treated in two stages [13]:

(1) The removal of coarse dust from the flue gas. This fraction has low zinc content $\left(<1 \mathrm{~g} \cdot \mathrm{kg}^{-1}\right)$ and can be directly recycled in the blast furnace via injecting or briquetting (Figure 1).

(2) Subsequently wet scrubbing for the removal of fine dust (BF sludge). In the EU, wet scrubbing is the technique most commonly applied as a second step in BF gas treatment. Scrubbing generates a contaminated waste water flow, which contains suspended solids (e.g. carbon and heavy metals). The separated solids (BFS) generate a waste problem because of heavy metals, especially zinc. The sludge from scrubbing is usually dewatered and either recycled or put to secure landfill until a suitable processing technique is available.

BFS contains valuable elements (Fe, C, etc.), but the high concentration of zinc and alkali are the major difficulty preventing the recycling of BFS to the blast furnace for recovering the Fe as pig iron, because zinc would evaporate and condense on furnace walls causing considerable disturbance [3] [4]. The condensed zinc prevents the descending of the furnace burden (the mixture of the iron ores, additives, and coke). This leads to a sudden descent of the load, which generates large amounts of dust and may even damage the installation and the tuyere damages of the furnace. The alkalis have an adverse effect on the furnace's performance, decreasing the hot strength of the coke and weakening the refractory lining [14]. To ensure proper working of the furnace, the input zinc and alkalis concentrations should not exceed an average value of $120 \mathrm{~g} /$ ton [10] and 250 - $300 \mathrm{~g} /$ ton [14], respectively, of pig iron.

Two representative blast furnace sludge samples from SSAB Europe Oy, Raahe, Finland, were obtained and investigated in this study. The Sludge samples were taken from the discharge of centrifuge. Once collected, samples were placed inside plastic bags to avoid contamination and transferred to the laboratory. Fresh blast furnace sludge was homogenized manually. Subsamples used for chemical and mineralogical analysis were dried at $75^{\circ} \mathrm{C}$. 


\section{Characterization Methods}

The Chemical composition of BFS was made by X-ray fluorescence (XRF). Bruker AXS S4 Pioneer X-ray fluorescence (XRF) spectrometer was used to determine the chemical composition of BFS samples. For performing XRF analysis, $13.16 \mathrm{~g}$ of ground sample was taken and mixed with $0.84 \mathrm{~g}$ of C-wax. WC/Co mortar HERZOG pulverizing mill was utilized to obtain homogeneous dispersion and uniform particle size of the resultant mixture (sorbent and C-wax). Pressed pellets for XRF analysis were prepared from the mixture $(7-8 \mathrm{~g})$ using boric acid as binder and applying a hydraulic pressure of 10 ton to compress the sample. The $\mathrm{pH}$ values of the sludge were measured after leaching $10 \mathrm{~g}$ of BFS with $25 \mathrm{~mL}$ of double deionized (DDI) water.

The crystalline phases of the BFS were determined by X-ray diffraction (XRD) using Rigaku SmartLab $9 \mathrm{~kW}$. The scan range from 4 to $90^{\circ} 2 \theta$ using a step size of $0.02^{\circ} 2 \theta$ and a step time of $1 \mathrm{~s}$ per step. The XRD analyses were done using 40 $\mathrm{kV}$ and $40 \mathrm{~mA}$.

The granulometric analysis of blast furnace sludge was determined using Beckman Coulter LS 13320. The morphological characteristic and the chemical composition of BFS particles were obtained by combined SEM-EDS using a Zeiss ULTRA plus field emission scanning electron microscope (FESEM), which was attached to an Energy-dispersive X-ray spectroscopy (EDS) unit for chemical analysis.

\section{Results and Discussion}

\subsection{Chemical Composition}

The chemical compositions of the two representative samples used in this study are shown in Table 1. It is clear that the chemical composition of the two samples is almost the same. The moisture content in the sludge is about $32.5 \%$. The $\mathrm{pH}$ varies depending on the $\mathrm{BF}$ raw material composition and the sieving performance of raw materials (BF slag, briquettes and limestone). The $\mathrm{pH}$ of the hot and cold water of the scrubber is 6069 and 6068, respectively. The $\mathrm{pH}$ values of BFS were in the range from 7.7 to 8.1 indicated that the blast furnace sludge is alkaline. Previous studies indicated that the alkalinity of BFS is due to high calcium oxide content [2] [15]. The carbonate is converted to calcium oxide in the upper shaft of the blast furnace. After disposal of the sludge, calcium oxide hydrolyzes to $\mathrm{Ca}(\mathrm{OH})_{2}$ and the $\mathrm{pH}$ is raised to an alkaline range.

Distribution of major elements of the BFS sample shows that Fe and $\mathrm{C}$ are the dominant elements in BFS. Large amounts of both elements are used in the blast furnace's operation in the form of metallurgical coke and iron ores. The air is blown through the blast furnace from the bottom upwards and carries over coke and iron ore particles into the top gas [2]. The contents of iron and carbon are $\left(378.5-389.5 \mathrm{~g} \cdot \mathrm{kg}^{-1}\right)$ and $\left(287-283 \mathrm{~g} \cdot \mathrm{kg}^{-1}\right)$, respectively. The sample also contains 70.7 - $71.7 \mathrm{~g} \cdot \mathrm{kg}^{-1} \mathrm{SiO}_{2} ; 66.0$ - $77.6 \mathrm{~g} \cdot \mathrm{kg}^{-1} \mathrm{CaO} ; 22.1$ - $27.0 \mathrm{~g} \cdot \mathrm{kg}^{-1} \mathrm{Al}_{2} \mathrm{O}_{3} ; 15.7$ $20.6 \mathrm{~g} \cdot \mathrm{kg}^{-1} \mathrm{MgO}$ and minor amounts of elements such as $\mathrm{S}$ and $\mathrm{Zn}$ (Table 1). 
Table 1. Chemical composition of the representative BFS samples.

\begin{tabular}{|c|c|c|c|c|c|}
\hline \multirow{2}{*}{ Element } & Sample A & Sample B & \multirow{2}{*}{ Element } & Sample A & Sample B \\
\hline & \multicolumn{2}{|c|}{ Major element $\left(\mathrm{g} \cdot \mathrm{kg}^{-1}\right)$} & & \multicolumn{2}{|c|}{ Trace element $\left(\mathrm{mg} \cdot \mathrm{kg}^{-1}\right)$} \\
\hline $\mathrm{Fe}$ & 389.5 & 378.5 & $\mathrm{~V}$ & 1474 & 1970 \\
\hline C content & 283 & 278 & $\mathrm{Ni}$ & 102 & 150 \\
\hline $\mathrm{CaO}$ & 77.6 & 66.0 & $\mathrm{Cu}$ & 20 & 67 \\
\hline $\mathrm{SiO}_{2}$ & 70.7 & 71.7 & $\mathrm{Rb}$ & 104 & 143 \\
\hline $\mathrm{MgO}$ & 15.7 & 20.7 & $\mathrm{Sr}$ & 84 & 115 \\
\hline $\mathrm{Al}_{2} \mathrm{O}_{3}$ & 22.1 & 27.0 & As & 50 & 119 \\
\hline $\mathrm{Na}_{2} \mathrm{O}$ & 4.2 & 4.0 & $\mathrm{Ga}$ & 26 & 35 \\
\hline $\mathrm{K} 2 \mathrm{O}$ & 3.2 & 2.5 & $\mathrm{Ba}$ & 130 & 184 \\
\hline $\mathrm{Zn}$ & 2.5 & 3.2 & Cs & 53 & 90 \\
\hline $\mathrm{F}$ & 2.5 & 2.0 & $\mathrm{Y}$ & 5 & 9 \\
\hline $\mathrm{P}_{2} \mathrm{O}_{5}$ & 1.7 & 2.3 & $\mathrm{Zr}$ & 19 & 20 \\
\hline S & 5.1 & 6.1 & Mo & 0 & 9 \\
\hline $\mathrm{TiO}_{2}$ & 2.6 & 3.6 & Sn & 8 & 9 \\
\hline $\mathrm{MnO}$ & 2.7 & 3.7 & $\mathrm{Sb}$ & 38 & 38 \\
\hline $\mathrm{Cr}_{2} \mathrm{O}_{3}$ & 0.10 & 0.1 & $\mathrm{La}$ & 11 & 10 \\
\hline $\mathrm{Pb}$ & 0.39 & 0.56 & $\mathrm{Ce}$ & 7 & 35 \\
\hline \multirow[t]{3}{*}{$\mathrm{Cl}$} & 0.58 & 0.78 & $\operatorname{Pr}$ & 4 & 4 \\
\hline & & & $\mathrm{Nd}$ & 11 & 27 \\
\hline & & & $\mathrm{Sc}$ & 4 & 4 \\
\hline $\mathrm{pH}$ & $7.7-8.1$ & & $\mathrm{Bi}$ & 14 & 30 \\
\hline \multirow[t]{2}{*}{ Moisture \% } & 32 & & Th & 2 & 2 \\
\hline & & & $\mathrm{U}$ & 2 & 2 \\
\hline
\end{tabular}

The iron and carbon contents of the studied BFS samples are relatively high compared to BFS studied by other researchers [2] [4] [10].

The concentration of $\mathrm{Zn}, \mathrm{Pb}$ and alkaline elements (such as $\mathrm{Na}$ and $\mathrm{K}$ ) is below $5 \mathrm{~g}^{\mathrm{kg}} \mathrm{kg}^{-1}$ in both samples A and B. The zinc content of this sample is low compared to BFS samples published earlier [2] [16]. The concentrations of $\mathrm{Zn}$, $\mathrm{Na} 2 \mathrm{O}, \mathrm{K} 2 \mathrm{O}$ and $\mathrm{Pb}$ are $\left(2.5-3.2 \mathrm{~g} \cdot \mathrm{kg}^{-1}\right),\left(4.0-4.2 \mathrm{~g} \cdot \mathrm{kg}^{-1}\right),\left(2.5-3.2 \mathrm{~g} \cdot \mathrm{kg}^{-1}\right)$ and $\left(0.3-0.5 \mathrm{~g} \cdot \mathrm{kg}^{-1}\right)$, respectively. These elements originate from impurities occurring in iron oxides, in the ash of coke and recycled materials. The samples also contain S (5 - $\left.6 \mathrm{~g} \cdot \mathrm{kg}^{-1}\right)$ and $\mathrm{P}\left(1.7-2.3 \mathrm{~g} \cdot \mathrm{kg}^{-1}\right)$ in low amount; $\mathrm{S}$ and $\mathrm{P}$ are bound in the organic framework of coke. $\mathrm{P}$ also originated from pellets which contain apatite, and $\mathrm{S}$ may appear as pyrite or marcasite [2].

Distributions of trace elements in the BFS samples are listed in Table 1. Vanadium records the highest concentrations range from 1474 to $1970 \mathrm{mg} \cdot \mathrm{kg}^{-1}$. Ba, $\mathrm{Ni}, \mathrm{Rb}, \mathrm{Sr}, \mathrm{As}, \mathrm{Cs}$ and $\mathrm{Cu}$ occur in relatively high concentrations (averages range from 50 to $184 \mathrm{mg} \cdot \mathrm{kg}^{-1}$ ). Elements such as Mo, Y, Zr, Sn, Sb, Ce, Nd and Bi ex- 
hibit relatively low concentrations (averages range from 4 to $38 \mathrm{mg} \cdot \mathrm{kg}^{-1}$ ). These results indicated that BFS is contaminated with $\mathrm{V}$, in addition to low contents of other harmful elements like As, Sr. The results reported by other researchers also indicated that BFS are contaminated.

\subsection{Mineralogical Composition}

The main crystalline phases of BFS sample were identified by XRD (Figure 2), in order of abundance, included hematite $\left(\mathrm{Fe}_{2} \mathrm{O}_{3}\right)$, calcite $\left(\mathrm{CaCO}_{3}\right)$, quartz $\left(\mathrm{SiO}_{2}\right)$ and magnetite $\left(\mathrm{Fe}_{3} \mathrm{O}_{4}\right)$ or maghemite $\left(\gamma-\mathrm{Fe}_{2} \mathrm{O}_{3}\right)$. No phases containing zinc or other alkaline elements were identified in the XRD analyses, due to the low amount of these elements $\left(2-5 \mathrm{~g} \cdot \mathrm{kg}^{-1}\right)$ which is hardly detectable by XRD. The sources of hematite and quartz phases are the iron ore pellets which was used during blast furnace operation. Quartz also originates from coke ash. Calcite originates from limestone, which is an additional material added to the blast furnace to produce a suitable blast furnace slag [16].

\subsection{Particle Size Distribution}

The granulometric analysis for BFS sample A is shown in (Figure 3 and Table 2). From the results of particle size analyzer, the BFS sample is characterized by different size fractions ranges and the average particle size $\left(d_{50}\right)$ is $18.42 \mu \mathrm{m}$. The main reason for different size distribution of BFS is usually the grade efficiency of the first separation stage. The granulometric analysis indicated that, this sample has a coarser size compared to granulometric analyses of BFS samples done by other researchers [2] [15] [16].

Figure 4 shows the XRD analyses for the different size fractions of BFS. From the XRD analyses, it is obvious that the hematite phase is concentrated in the fine fraction, which is in agreement with results reported by other researchers [1]. They concluded that the metals are more concentrated in the fine fraction of the sludge. Table 2 presents the granulometric analysis and the main mineral's

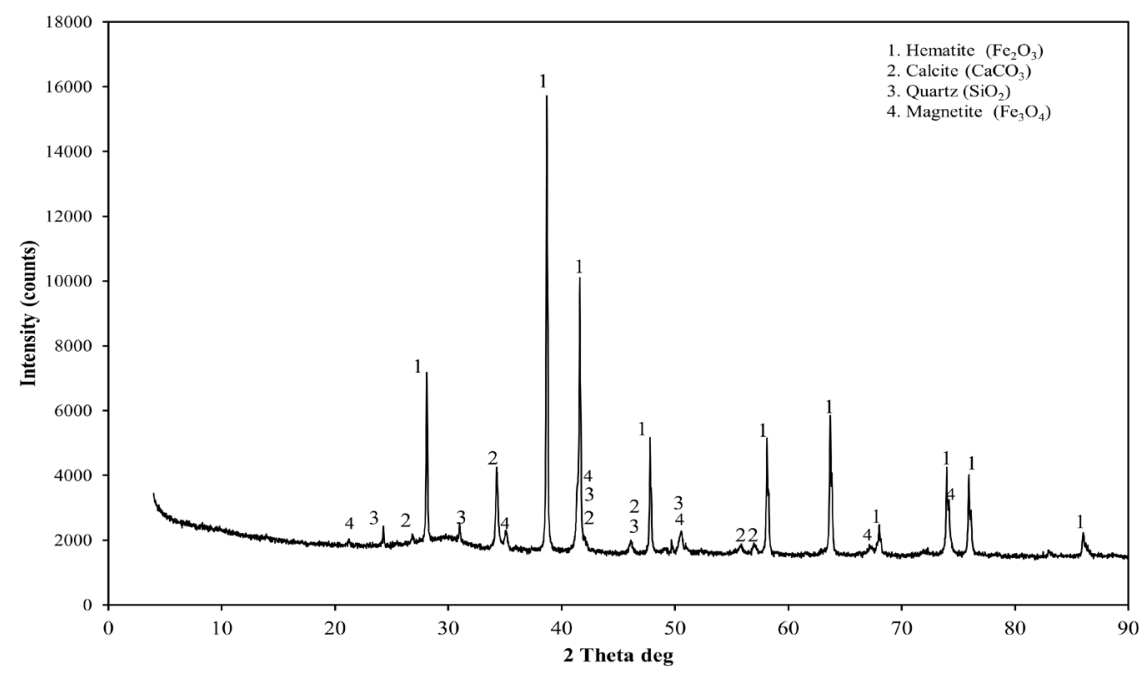

Figure 2. X-ray diffraction pattern for BFS. 


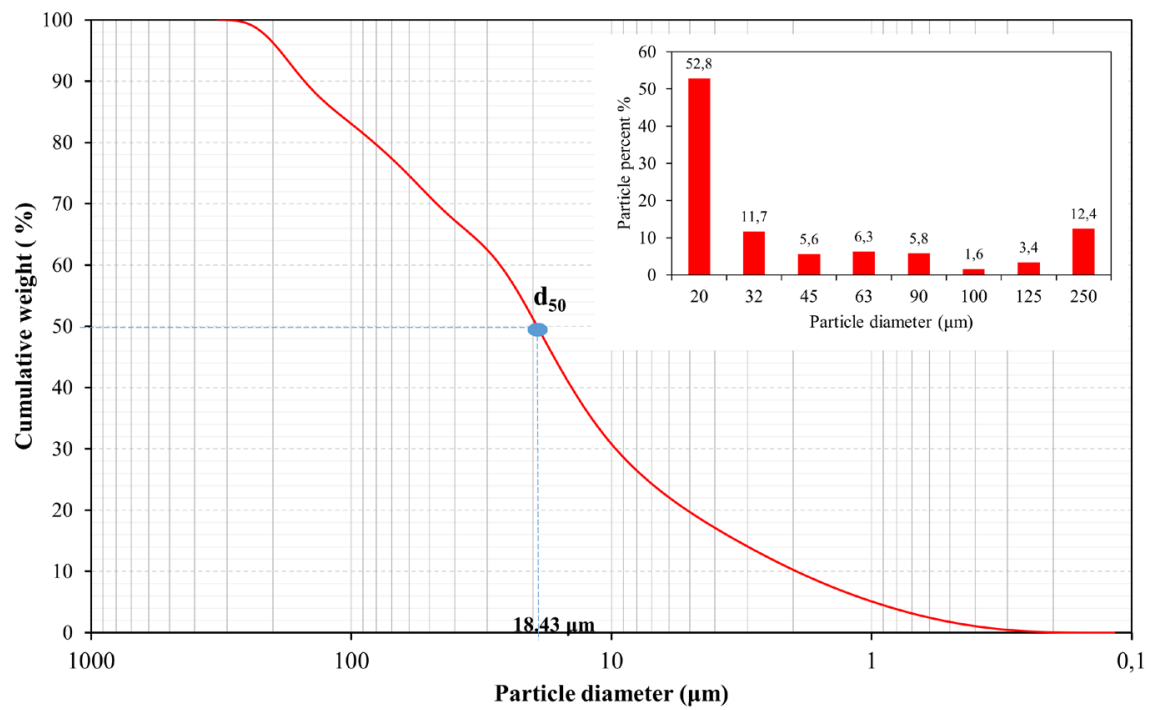

Figure 3. Particle size distribution of BFS.

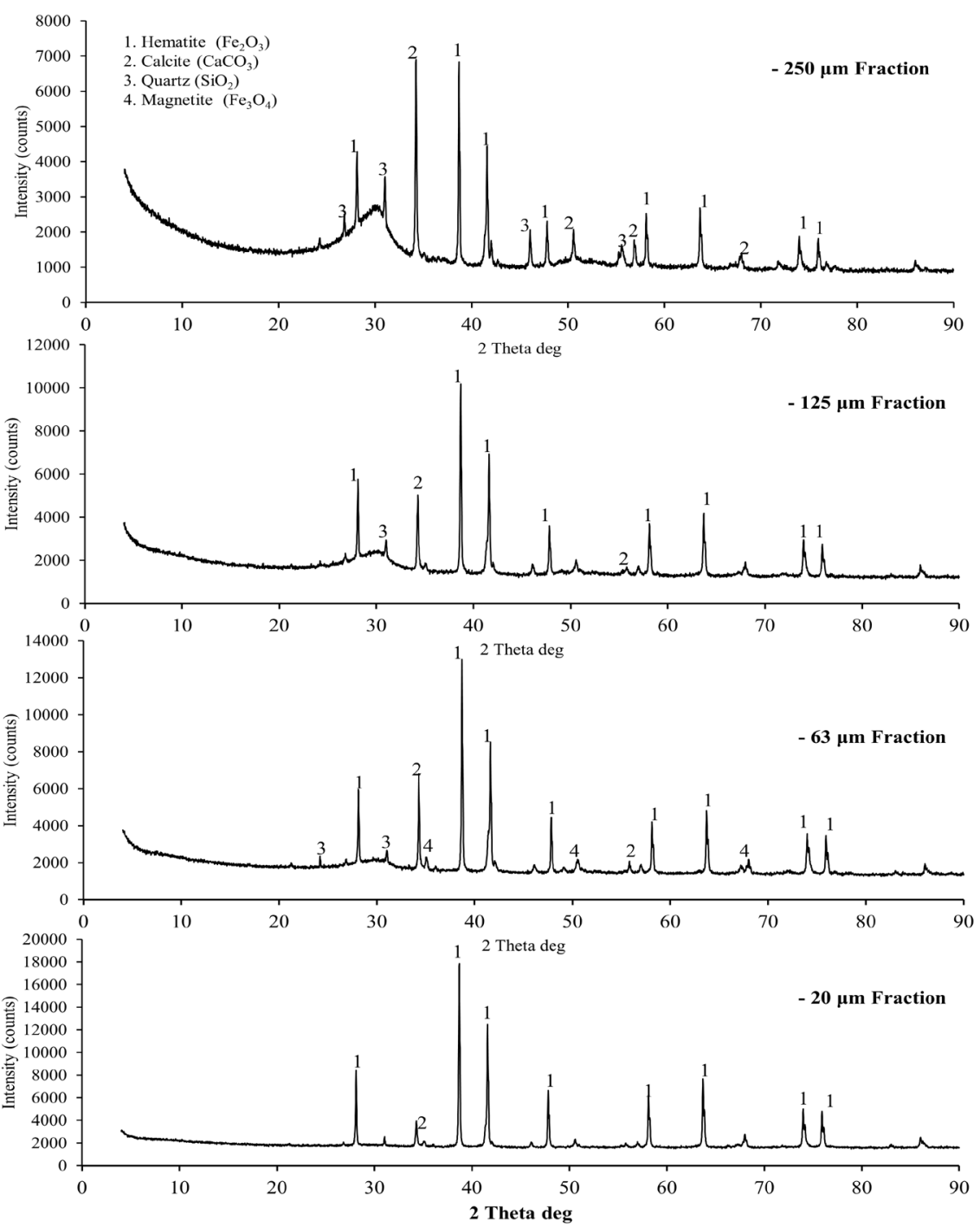

Figure 4. X-ray diffraction patterns for different size fractions of BFS. 
Table 2. Granulometric analysis of BFS.

\begin{tabular}{|c|c|c|c|}
\hline Particle size $(\mu \mathrm{m})$ & Weight \% & Cumulative \% & Mineralogical composition \\
\hline 20 & 52.8 & 52.8 & $\begin{array}{l}\text { Dominated with hematite }(>80 \%) \text {, } \\
\text { with less of carbon and calcite }\end{array}$ \\
\hline 32 & 11.7 & 64.5 & \\
\hline 45 & 5.6 & 70.1 & $\begin{array}{l}\text { Dominated with hematite ( } 60 \%-45 \%) \text {, with } \\
\text { high calcite, quartz and carbon content }\end{array}$ \\
\hline 63 & 6.3 & 76.4 & \\
\hline 90 & 5.8 & 82.2 & Dominated with hematite, carbon and calcite \\
\hline 100 & 1.6 & 83.8 & Dominated with carbon, calcite and \\
\hline 125 & 3.4 & 87.2 & hematite with less quartz \\
\hline 250 & 12.4 & 99.6 & $\begin{array}{l}\text { Dominated with carbon, quartz and calcite } \\
\text { with less hematite }\end{array}$ \\
\hline Median (d50) & $18.41 \mu \mathrm{m}$ & & \\
\hline $\mathrm{d}_{10}=1.84$ & $\mathrm{~d}_{25}=6.97$ & $\mathrm{~d}_{50}=18.42$ & \\
\hline $\mathrm{d}_{75}=58.37$ & $\mathrm{~d}_{90}=144.1$ & $d_{100}=228.6$ & \\
\hline
\end{tabular}

phases in each fraction. The dominating crystalline phase identified in the very fine fraction $(<20 \mu \mathrm{m})$ is hematite, but zinc cannot be identified due to the peak overlap with magnetite. On the other side, the coarser fraction is mostly X-ray amorphous (coke), and the main crystalline phases are quartz, calcite and hematite. An increased background (between $20^{\circ}$ and $30^{\circ} 2 \theta$ ) in the XRD pattern indicates the presence of amorphous compounds. This result indicated that iron phases are concentrated in the fine fraction $<20 \mu \mathrm{m}$ of sludge. Such fine particles are very difficult to beneficiate via conventional mineral processing processes (e.g., gravity and magnetic separation).

\subsection{SEM-EDS}

The morphology and the chemical composition of particles of the BFS sludge were investigated by means of SEM-EDS. The SEM images show that BFS is composed mainly of hematite, as its iron-bearing phase, and carbon, in addition to fractions of silicate and carbonate materials (Figure 5(A)). Different morphological types were observed during SEM investigation. Figure 5(B) shows that hematite mostly is presented as aggregates of particles of irregular shape (most hematite crystals measure below $20 \mu \mathrm{m}$ ). Coke occurs as elongated crystals (Figure 5(C) and Figure 5(D)) of larger particle size (> $125 \mu \mathrm{m}$ ); also hexagonal grain of graphite is observed. Some detrital hematite particles $(<10 \mu \mathrm{m})$ are found inside coke particle (Figure 5(D)). Aluminum silicate inclusions are also detected inside coke particles (Figure 5(E)). The carbonate and silicate materials are detected in the larger size fraction as massive aggregates and become more concentrated in fraction above $125 \mu \mathrm{m}$ (Figure 5(F)). These results are consistent with the results obtained from the granulometric analyses of the sample, which indicates that the sample has a heterogeneous particles distribution and iron bearing minerals are more concentrated in the fine fraction of the sludge $(<$

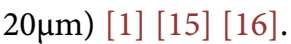



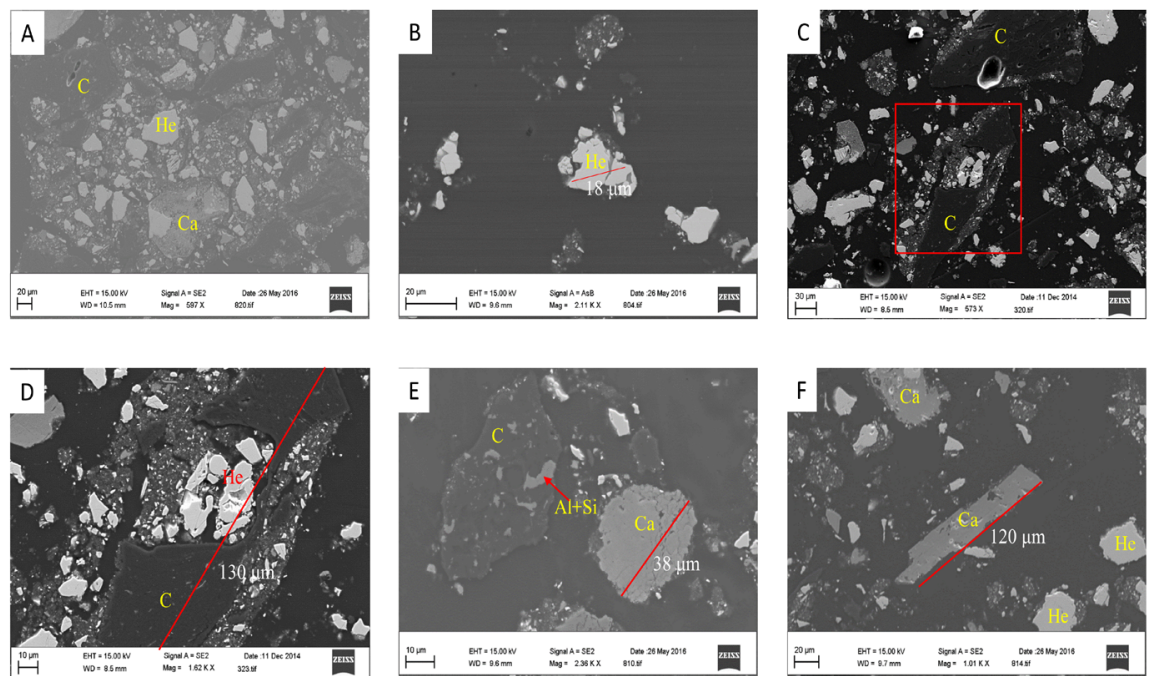

Figure 5. (A) SEM image of blast furnace sludge shows the sample composed mainly of Hematite $(\mathrm{He})$ and coke $(\mathrm{C})$; (B) Irregular hematite $(\mathrm{He})$ particles $(<18 \mu \mathrm{m})$; (C) Elongated crystals of Coke (C) $(>135 \mu \mathrm{m})$; (D) Enlargement of square in (C) shows detrital hematite $(\mathrm{He})$ inside coke particle $(\mathrm{C})$; (E) Calcite $(\mathrm{Ca})$ and coke particle with aluminum silicate $(\mathrm{Al}+\mathrm{Si})$ inclusion; $(\mathrm{F})$ Elongated calcite $(\mathrm{Ca})$ particle $(>120 \mu \mathrm{m})$

The EDS spectrum confirms the presence of the main elements in the BFS sample, which is in agreement with the results of chemical analysis. Due to the low concentration of zinc in the sample $\left(<2.5 \mathrm{~g} \cdot \mathrm{kg}^{-1}\right)$, it is difficult to detect the zinc bearing phase in the BFS sample. For this reasons, different size fractions $<20,+20-45,+45-63,+63-125,+125-250$ and $>250 \mu \mathrm{m}$ of the BFS were analyzed with SEM and EDS. From investigation, the hematite content increased as particle size of the sample decreased. In the fine fraction $(<20 \mu \mathrm{m})$ of the sludge, iron bearing particles are more concentrated together with zinc phase (Figure 6). Particles rich in zinc and iron were detected in the fine fraction $(<20$ $\mu \mathrm{m}$ ) of the sludge (Figure $6(\mathrm{~B})$ ) by using EDS. These results suggest that $\mathrm{Zn}$ in BFS investigated may be presented as zinc ferrite [2] [10]. On the other hand, the nonferrous minerals contents increase with increasing particle size fraction. The coke, calcite and aluminum silicate are more concentrated in the coarser fractions $(125-250 \mu \mathrm{m})$ (Figure 7), which is in agreement with the results of granulometric analysis. Based on this result, hydrometallurgical methods are not suitable for zinc removal from this waste because zinc ferrite is quite stable and insoluble in most acidic and alkaline solutions.

Figure 8 shows EDS distribution map of $\mathrm{Fe}, \mathrm{C}, \mathrm{Ca}, \mathrm{Si}, \mathrm{Al}$ and $\mathrm{Zn}$ elements in order to clarify their distribution in the BFS sample. The EDS distribution maps show that the distribution of iron interferes with carbon distribution, carbon is concentrated in the large particles size, while iron has a higher concentration in the fine particles surrounding carbon particles. The distribution of $\mathrm{Ca}$ is related to calcite and occurs in large fraction. Due to the low concentration of zinc the distribution map of zinc is not clear enough, but the map shows that zinc is more concentrated in the area of high iron concentration (Figure 8). 

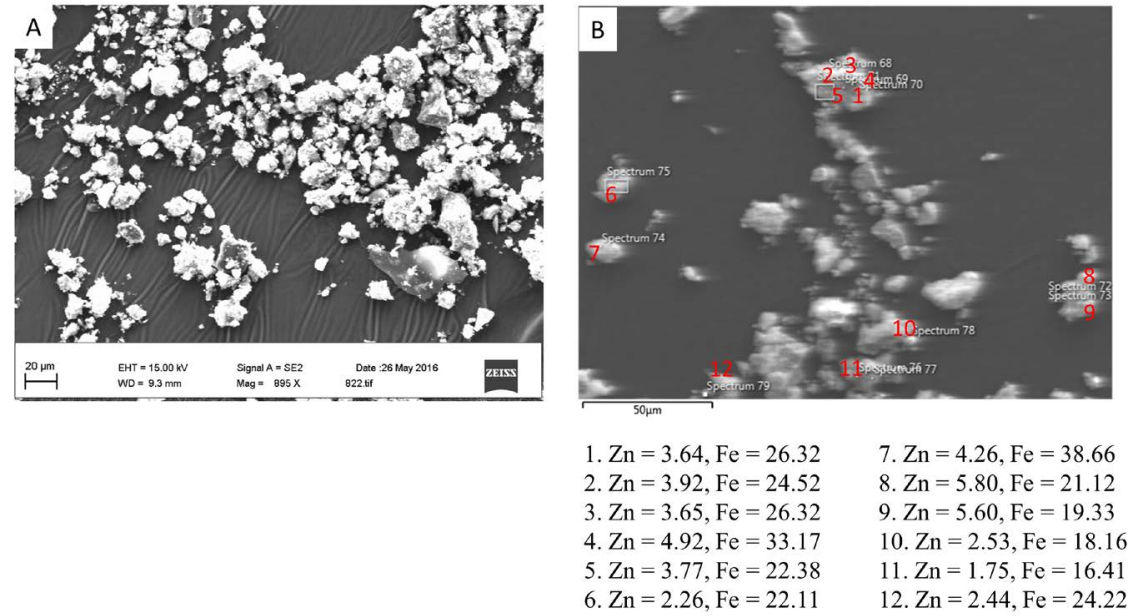

Figure 6. (a) SEM image for fraction less than $20 \mu \mathrm{m}$; (b) SEM and EDX analyses show fine particles $(<20 \mu \mathrm{m})$ of the sludge are rich in iron and zinc.

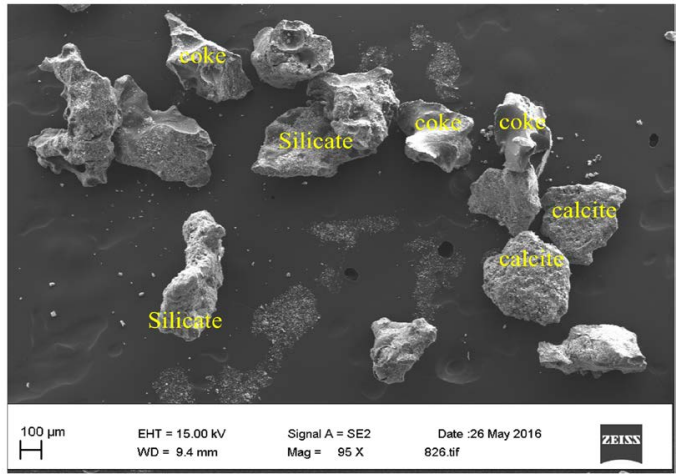

Figure 7. SEM for the coarser fraction $(125-250 \mu \mathrm{m})$ shows that this fraction is rich in coke, calcite and quartz.
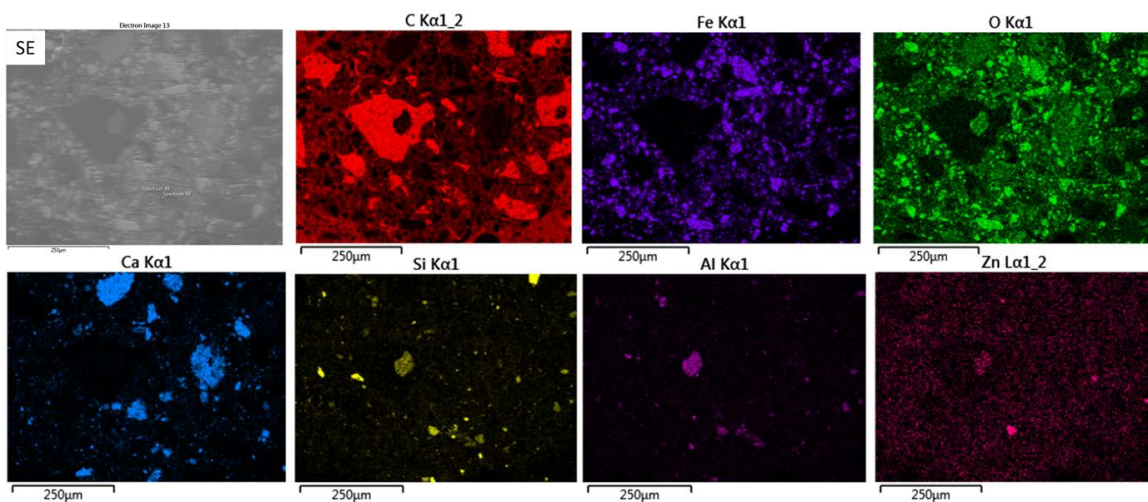

Figure 8. EDS distribution maps for $\mathrm{Fe}, \mathrm{C}, \mathrm{Ca}, \mathrm{Si}, \mathrm{Al}$ and $\mathrm{Zn}$ elements in the $\mathrm{BFS}$ sample.

\section{Implications of Present Study for Utilization of Blast Furnace Sludge}

For the utilization of blast furnace sludge in iron and steel making industries many pyrometallurgical, hydrometallurgical processes or a combination of both have been developed, each of these methods have advantages and disadvantages. 
The pyrometallurgical methods have some economic and environmental problems due to high-energy requirements and the need for dust collection and gas cleaning systems [3] [17] [18]. On the other hand, the major disadvantage of hydrometallurgical treatment is that, the majority of zinc in these materials is found as zinc ferrite (franklinite) which is quite stable and insoluble in most acidic and alkaline solutions [19]. The choice between pyrometallurgical or hydrometallurgical processing strongly depends on the properties of materials [20]. The factors which determine the suitable processing method are: the mineralogical composition of sludge, zinc form (zinc oxide or zinc ferrite), concentration of zinc and alkali elements, concentration of valuable metals, and particle size of sludge. Therefore, before choosing the processing method, a detailed characterization of waste is an essential step for determining the most appropriate recycling strategy [20].

In the present study, the determination of concentration and mode of occurrence of iron, zinc and other harmful elements in the BFS can help to design the suitable process to recycling BFS in the iron and steel making industries. Results of the current study indicated that physical separation methods and hydrometallurgical methods are not suitable to process this waste. The hematite fine particles $(3-20 \mu \mathrm{m})$ are very difficult to recovery through physical separation processes (e.g., gravity and magnetic separation). On the other hand, hydrometallurgical methods are not effective to remove zinc from BFS, because zinc mainly occurs in the zinc ferrite phase which is quite stable and insoluble in most acidic and alkaline solutions. The main difficulties in the handling of these sludges are the high moisture content and very fine particles size of BFS. The characterization of BFS indicated that the sample shows relatively high contents of $\mathrm{Fe}$ and $\mathrm{C}$. Briquettes and pelletization represent a potential method for recycling of blast furnace sludge or part of the sludges again as a feed material to furnace, and due to high $\mathrm{Fe}$ and $\mathrm{C}$ content it can be utilized as self-reducing material.

\section{Conclusion}

The present study gives a detailed characterization of blast furnace sludge from SSAB Europe Oy, Raahe, Finland, in order to determine the most appropriate recycling method. The results showed that, BFS shows relatively high contents of iron $(\mathrm{Fe})\left(390 \mathrm{~g} \cdot \mathrm{kg}^{-1}\right)$, and carbon (C) $\left(290 \mathrm{~g} \cdot \mathrm{kg}^{-1}\right)$, while the concentration of zinc $(\mathrm{Zn})\left(2.5 \mathrm{~g} \cdot \mathrm{kg}^{-1}\right)$ is low. SEM-EDX analyses indicated that, hematite and zinc ferrite are more concentrated in the very fine fraction $(<20 \mu \mathrm{m})$, while the coarser fraction $(90-250 \mu \mathrm{m})$ is dominated by calcite, quartz and X-ray amorphous coke. Based on the achieved results, physical separation methods are not suitable to recovery valuable minerals from this waste due to hematite with very fine particles size $(3-20 \mu \mathrm{m})$. Due to the low concentration and mode of occurrence of zinc in the BFS, hydrometallurgical methods are also not suitable to remove zinc from BFS. On the other hand, briquettes represent a potential method for handling of sludges and use them again as a feed material to the blast furnace. 


\section{Acknowledgements}

The authors would like to thank Mr. Olli Mattila and Mr. Timo Paananen from SSAB Europe for the discussions and for their offers of industrial samples. The authors thank Mr. Riku Mattila and Mr. Tommi Kokkonen for their technical support throughout this work. The authors are indebted to Mrs. Leena Palmu for the XRF analyses and Mr. Jarno Karvonen for granulometric analyses.

\section{References}

[1] Machado, J.G., Brehm, F.A., Moraes, C.A., Santos, C.A., Vilela, A.C. and Cunha, J.B. (2006) Chemical, Physical, Structural and Morphological Characterization of the Electric Arc Furnace Dust. Journal of Hazardous Material, 136, 953-960. https://doi.org/10.1016/j.jhazmat.2006.01.044

[2] Mansfeldt, T. and Dohrmann, R. (2004) Chemical and Mineralogical Characterization of Blast-Furnace Sludge from an Abandoned Landfill. Environmental Science and Technology, 38, 5977-5984. https://doi.org/10.1021/es040002+

[3] Trung, Z.H., Kukurugya, F., Takacova, Z., Orac, D., Laubertova, M., Miskufova, A. and Havlik, T. (2011) Acidic Leaching Both of Zinc and Iron from Basic Oxygen Furnace Sludge. Journal of Hazardous Material, 192, 1100-1107. https://doi.org/10.1016/j.jhazmat.2011.06.016

[4] Van Herck, P., Vandecasteele, C., Swennen, R. and Mortier, R. (2000) Zinc and Lead Removal from Blast Furnace Sludge with a Hydrometallurgical Process. Environmental Science and Technology, 34, 3802-3808.

https://doi.org/10.1021/es9910331

[5] Das, B., Prakash, S., Reddy, P.S.R. and Misra, V.N. (2007) An Overview of Utilization of Slag and Sludge from Steel Industries. Resources, Conservation \& Recycling, 50, 40-57. https://doi.org/10.1016/j.resconrec.2006.05.008

[6] Mombelli, D., Di Cecca, C., Mapelli, C., Barella, S. and Bondi, E. (2016) Experimental Analysis on the Use of BF-Sludge for the Reduction of BOF-Powders to Direct Reduced Iron (DRI) Production. Process Safety and Environmental Protection, 102, 410-420. https://doi.org/10.1016/j.psep.2016.04.017

[7] Environmental Protection Agency (2002) European Waste Catalogue and Hazardous Waste List.

[8] Mansfeldt, T. and Dohrmann, R. (2001) Identification of a Crystalline CyanideContaining Compound in Blast-Furnace Sludge Deposits. Journal of Environmental Quality, 30, 1927-1932. https://doi.org/10.2134/jeq2001.1927

[9] Földi, C., Dohrmann, R. and Mansfeldt, T. (2014) Mercury in Dumped Blast Furnace Sludge. Chemosphere, 99, 248-253.

https://doi.org/10.1016/j.chemosphere.2013.11.007

[10] Kretzschmar, R., Mansfeldt, T., Mandaliev, P.N., Barmettler, K., Marcus, M.A. and Voegelin, A. (2012) Speciation of $\mathrm{Zn}$ in Blast Furnace Sludge from Former Sedimentation Ponds Using Synchrotron X-ray Diffraction, Fluorescence, and Absorption Spectroscopy. Environmental Science and Technology, 46, 12381-12390. https://doi.org/10.1021/es302981v

[11] Huiting, S. and Forssberg, E. (2003) An Overview of Recovery of Metals from Slags. Waste Management, 23, 933-949. https://doi.org/10.1016/S0956-053X(02)00164-2

[12] Wang, C., Jennes, R., Mattila, O., Paananen, T., Lilja, J. and Larsson, M. (2015) Investigation of Applying OxyCup ${ }^{\circledR}$ Process for an Integrated Steel Plant from a Nordic Country. Düsseldorf, 15-19 June 2015, 1-5. 
[13] (2013) Best Available Techniques (BAT) Reference Document for Iron and Steel Production, Industrial Emissions Directive 2010/75/EU, Integrated Pollution Prevention and Control. Publications Office of the European Union, Luxembourg.

[14] Kurunov, I.F., Titov, V.N., Emel'yanov, V.L., Lysenko, S.A. and Arzamastsev, A.N. (2009) Analysis of the Behavior of Alkalis in a Blast Furnace. Metallurgist, 53, 533 542. https://doi.org/10.1007/s11015-010-9210-8

[15] Vereš, J., Jakabský, Š. and Šepelák, V. (2010) Chemical, Physical, Morphological and Structural Characterization of Blast Furnace Sludge. Diffusion Fundamental, 12, 8891.

[16] Vereš, J., Lovás, M., Jakabský, Š., Šepelák, V. and Hredzák, S. (2012) Characterization of Blast Furnace Sludge and Removal of Zinc by Microwave Assisted Extraction. Hydrometallurgy, 129-130, 67-73. https://doi.org/10.1016/j.hydromet.2012.09.008

[17] Jha, M.K., Kumar, V., and Singh, R.J. (2001) Review of Hydrometallurgical Recovery of Zinc from Industrial Wastes. Resources, Conservation \& Recycling, 33, 1-22. https://doi.org/10.1016/S0921-3449(00)00095-1

[18] Orhan, G. (2005) Leaching and Cementation of Heavy Metals from Electric Arc Furnace Dust in Alkaline Medium. Hydrometallurgy, 78, 236-245. https://doi.org/10.1016/j.hydromet.2005.03.002

[19] Elgersma, F., Kamst, G.F., Witkamp, G.J. and Van Rosmalen, G.M. (1992) Acidic Dissolution of Zinc Ferrite. Hydrometallurgy, 29, 173-189. https://doi.org/10.1016/0304-386X(92)90012-O

[20] Dutra, A.J.B., Paiva, P.R.P. and Tavares, L.M. (2006) Alkaline Leaching of Zinc from Electric Arc Furnace Steel Dust. Mineral Engineer, 19, 478-485. https://doi.org/10.1016/j.mineng.2005.08.013

\section{Submit or recommend next manuscript to SCIRP and we will provide best} service for you:

Accepting pre-submission inquiries through Email, Facebook, LinkedIn, Twitter, etc. A wide selection of journals (inclusive of 9 subjects, more than 200 journals)

Providing 24-hour high-quality service

User-friendly online submission system

Fair and swift peer-review system

Efficient typesetting and proofreading procedure

Display of the result of downloads and visits, as well as the number of cited articles

Maximum dissemination of your research work

Submit your manuscript at: http://papersubmission.scirp.org/

Or contact jmmce@scirp.org 